that the shoes were indeed modern ones. For some of the models the captions should have been "As worn in old Pekin," or "Hallux valgus guaranteed in three months and bunions in one year." Others again looked guaranteed to cripple in six months. I then realized that I was looking at "fashion shoes of high décor." My mind went back to the anatomy I had learnt and taught, and to the human feet I had seen.

What has happened to women's shoes? Many of the present models have little relationship to the anatomy or physiology of the normal human foot. They produce a self-conscious and stilted gait with hardly any normal movement at the ankle joint, and the slightest wearing of the pencil-point heels produces valgus or varus deformity or wobble of the whole foot during walking. Yet these shoes have become so fashionable that there is a demand that buses, escalators, and gratings should be modified to avoid danger. They must be extremely uncomfortable, since the royal parks in summer are filled with women resting their feet with their shoes by their sides.

There is, however, a practical problem involved. In a certain proportion of my patients I have to take some interest in the type of footwear which is being worn. Over the past few years it has become clear that many women are finding it more and more difficult to get reasonable walking shoes for normal feet. On inquiry I find that they have tried shop after shop without success. Some wellknown firms seem to have given up the manufacture of ordinary walking shoes, and at one shop which was, in the past, celebrated for the quality, style, and normality of its shoes, a lady was recently informed that they now only sold high décor shoes and they advised her to go to an orthopaedic shoe-maker. Another lady, who had previously had no trouble at all in getting shoes, recently spent a whole day in London shoe-shops in a completely vain endeavour to get reasonable shoes.

My interest is not merely clinical. I spent the whole of my early life in a county celebrated for its boots and shoes and in a town whose manufacture of these has a worldwide reputation. I have visited many boot factories, I have known hundreds of clickers, finishers, closers, and men in the rough stuff room, and I know the quality of their workmanship. Even years ago, many of the firms took th: greatest possible interest in the anatomy and physiology of the foot and made every endeavour to relate this to the design and quality of the footwear they produced. I wonder what the craftsmen think of some of the shoes that are now being produced? The explanation of the present position is that the fashions are entirely commercial. How far is this due to the altered financial structure of the boot and shoe industry? Children's shoes are very satisfactory, but they become more and more abnormal and commercial as the girl of teenage is approached. Many of the women who are wearing contemporary shoes get pain in the calf, oedema of the foot, hallux valgus, and fatigue, to say nothing of the more serious injuries, such as sprains and fractures. It has been estimated that $75 \%$ of girls leaving school have hallux valgus. These represent potential patients in the future. All these matters are related to the cost of the Health Service. If animals were treated with the degree of inhumanity to which women now are prepared to subject their feet at the behest of the boot manufacturers, there would be an outcry from all the humanitarian societies in the country. A young doctor, uncertain of the future, might do worse than take up the study of chiropody, for it will obviously be of increasing importance. Eventually he might become a consultant and serve on Government commissions, or an industrial adviser on feet, or he might turn to politics. Whichever course he finally chose, he would have valuable knowledge as to where the shoe really pinches.

As an immediate step, I suggest that the Minister of Health has a talk with the President of the Board of Trade. It might even be necessary to promulgate new sumptuary laws in connexion with women's footwear in order to save the tax-payer and the Treasury.-I am, etc.,

London, W.1.

\section{Scapulo-thoracic Crackling in Youth}

SIR,-Some time before the second world war, at the German Hospital in London, I was asked by one of the German house staff to see a young Englishwoman living in the neighbourhood of the hospital who had come to the out-patient department. On movement of the shoulderblades a peculiar kind of crackling could be felt (not heard) over the region of the shoulders at the back of the thorax, apparently unaccompanied by any pain or even disagreeable sensation. This young woman was not in the least afraid nor wished to appear ill, but simply wanted to know the nature of her condition, and whether she ought to do anything about it. On examination the "crackling" seemed clearly to be due to some unusual unevenness of development between the scapulae and the bony cage of the thorax. It could hardly be called crepitous, and certainly there was no actual bony grating, such as may be due to exposed bony surfaces after a fracture. She seemed perfectly normal in every other respect. The chief questions in my mind were whether one was justified in assuming that the abnormality was "rheumatoid" in nature and if it varied at all with the weather. Was it likely to increase or diminish with the age of the patient? Such abnormalities were associated in my mind with changes commonly occurring in later life. One had heard the wellknown lines in Dr. Edward Jenner's (the vaccination Jenner) famous poem on the signs of the weather :

"Hark how the chairs and tables crack;

Old Betty's joints are on the rack."

But there were no pains in this case, nor need there be any pain associated with obvious so-called osteoarthritic changes in later life. As a matter of fact, I need go no further than my own person in that regard. Sometimes, on movement of my neck during conversation, a loud crack can be heard, though I feel nothing whatever, and the sound only interrupts my talk. In this young woman, the crackling which one felt with one's hands on her shoulders was obviously of the same nature as crackling which can actually be heard, but I do not know of any other case of crackling like this in youth, or even in elderly people. Minor degrees, I believe, are not rare, though they have attracted very little attention.

On the whole, I thought it better not to advise any special treatment. The young woman was desirous of making a holiday tour in Germany, and, hearing this, the residents of the German Hospital invited her to tea in order to work out the best itinerary for her and her father. It happened that my wife and I met them on the crossChannel steamer. She introduced us to her father. Her peculiar symptoms remained much the same, and I determined to bring her to a meeting of the clinical section of the Royal Society of Medicine. Mr. Duncan Fitzwilliams was then the president of the section, and I got him to examine her carefully. His commanding figure, great knowledge, and pleasant manner could certainly do no harm. With his hands on her shoulder-blades he said very seriously: "Ah, those are where the wings were amputated." The meeting was a very large one, but beyond this gallant remark I could get no other information worth mentioning. My case was quite rightly not reported in the published account of the meeting.

At the end of the second world war I ascertained by letter that the crackling was still present, apparently neither better nor worse. I now regard the case as a little-known abnormality of development, allied to other conditions, such as camptodactylia of Landouzy, often associated with varying degrees of Dupuytren's contraction of the palmar fascia. Such abnormalities may commence to show themselves as varying ages, often excited by local traumatisms ; then after reaching a certain stage they tend to remain stationary or regress. In middle age my father, my eldest sister, and myself suffered from a peculiar chronic tenderness about the metacarpo-phalangeal joint of both index fingers, which might have been thought to be of so-called 
gouty nature, but in later life it completely disappeared without special treatment. In my own person the Dupuytren's patchy thickenings of the palmar fascia have practically disappeared, though of course the camptodactylia of the fourth and fifth fingers must be expected to remain. I am inclined to think that a congenital bent little finger, with slight webbing to the fourth finger, may be regarded as a non-progressive variety of Landouzy camptodactylia. -I am, etc.,

London, N.W.1.

\section{F. Parkes Weber.}

\section{Hospital Confinement}

SIR,-Even although the antenatal period has been uneventful, the position of the foetus normal, and the mother in excellent condition, the actual labour is always an anxious time. Surely, then, it is best to deliver the mother in a maternity unit where all modern resources are immediately available should the need arise, and she should be delivered by the G.P.-obstetrician-midwife team who have supervised her antenatal care. In most cases all will go well, and after an hour or two's rest the mother and baby, accompanied by the midwife, could go home by ambulance. Nursing would be continued as in a domiciliary confinement. The labour would be conducted under ideal conditions, and going home so soon would lessen the risks of cross-infection. Such a scheme, already described in detail, ${ }^{1}$ would require the closest co-operation between the G.P.-obstetrician, midwife, and consultant-obstetrician.-I am, etc.,

Bristol.

J. Sluglett.

REFERENCE

1 Sluglett, J., and Walker, S., Lancet, 1956, 1, 684.

SiR,-Dr. J. P. O'Dwyer states (Journal, April 20, p. 947) that "it is so much safer to have a baby in hospital than in the home." It would be interesting to have the facts on which he bases this statement.-I am, etc.,

Newcastle upon Tyne, 2.

Frank Stabler.

\section{Pulmonary Embolism Following Ear Operations}

SIR,-I have recently had two patients who suffered from pulmonary embolism following clean operations on the ear. Neither patient showed any abnormality of the cardiovascular system before operation and a careful search did not reveal any sign of thrombosis in the extremities after operation. In both cases the operations were prolonged, one fenestration and one for bilateral removal of osteomata from the meatus.

In my experience pulmonary embolism is so rare after operations on the ear that I feel that these cases call for comment. I would be grateful for any information as to the experience of others in similar cases and particularly as to whether they were associated with the use of chlorpromazine or similar drugs.-I am, etc.

Dublin.

V. O. MCCORMICK.

\section{Budgerigars in Wards}

SIR,-I should like to reply to Dr. N. A. Thorne (Journal, April 27, p. 1008), as one who keeps a variety of birds as a hobby. He makes reference to the danger of psittacosis. In spite of there being a rigid import ban on budgerigars, I personally am very concerned about the manner in which seamen can bring these birds into the country. I am not altogether satisfied that the regulations are observed. Fortunately the disease has not been known in this country for several years, but should it appear it would be extremely difficult to diagnose other than under the title of virus pneumonia.

Although the budgerigar is a most interesting and charming pet, it could be rather a nuisance to the patient who was very ill. Not only that: kept in cages, they are constantly moulting, and there is always a fine dust in and around the cages derived from feathers, skin, food, and excreta. This would adversely affect people allergic to dusts.
In my opinion these pets are not really suitable for general wards, but eminently desirable in outside aviaries where they could be seen from the wards or visited by the patients. I would like to recommend Bengalese or zebra finches as ward pets. They do not create a din; they are tightfeathered and very clean and healthy; they are constantly on the move and are extremely interesting.

I would conclude by stating that in my opinion some type of living creature, such as bird or fish, is very desirable in certain wards, relieving the somewhat drab background. -I am, etc.,

Dalry, Ayrshire.

Alex. Watt.

\section{Sexing Cells}

SIR,-Since 1954 we have been sexing cells. ${ }^{1-3}$ We have always done so in fresh, unfixed, unstained material-oral, genital, urinary epithelial cells, tumour surface scrapings, amniotic fluid sediment, etc.-observed with the phasecontrast microscope. The method is simple and very rapid.

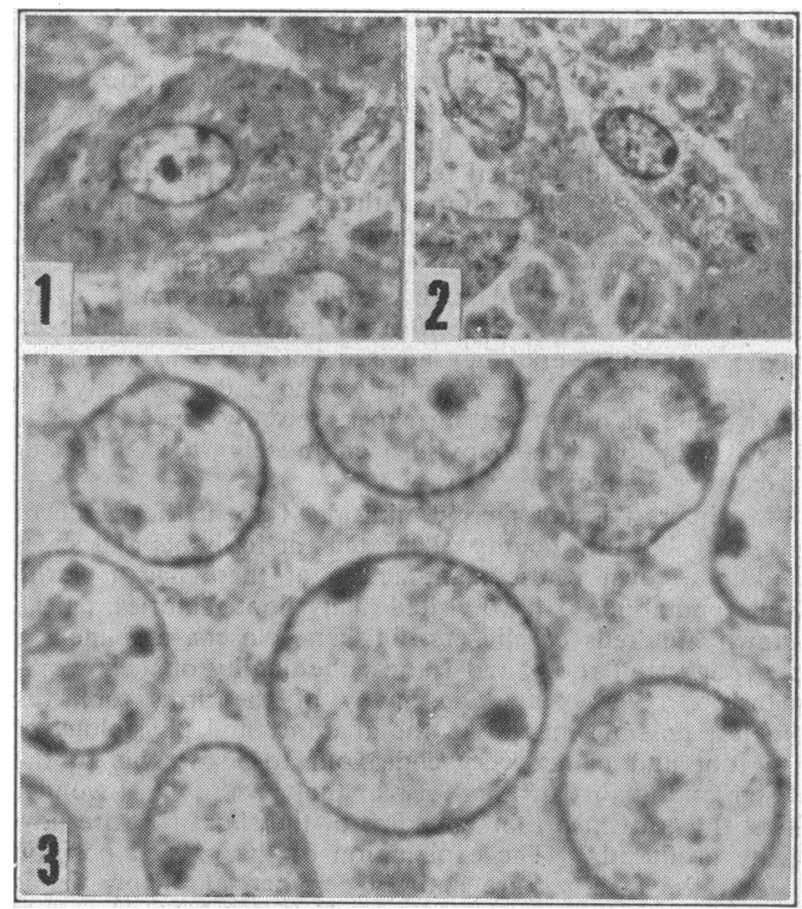

FIG. 1.-Sex chromatin in epithelial cell of female urethra. FIG. 2.- Sex chromatin in epithelial cell of female urethral polyp ( $\times 950)$. FIG. 3.-Sex chtomatin in cells of thyroid cancer (female) $(\times 950)$.

Results are as reliable as those obtained with the observation of stained preparations. Counts of sex chromatin are based only on the presence of planoconvex masses in intimate contact with the inner surface of the nuclear membrane (see photomicrographs).-I am, etc.,

Santiago, Chile. REFERENCES

EdNa Silva-InzunZa.

1 Coutts, W. E., and Silva-Inzunza, E., Rev. Soc. chil. Urol., 1955, 18, 70.

2 - and Coutts, W. R., J. Urol. méd. chir., 1955, 61, 828.

\section{Thyroid Disorders in the Newborn}

SIR,- - The paper on thyroid disorders in the newborn by Drs. I. D. Riley and G. Sclare (Journal, April 27, p. 979) brought to my mind the case of a former patient of mine, aged 30 years, who in 1924 suffered from a large adenomatous goitre for which she refused any kind of treatment. On two occasions I delivered this woman of a male child; each was born with a well-marked goitre, but each was stillborn. From the size of the goitre $I$ believe there is little doubt that the cause of death in each case was respiratory obstruction from pressure by a nodular goitre. This observa- 